\title{
Hubungan Indeks Bentuk Telur dan Surface Area Telur terhadap Bobot Telur, Bobot Tetas, Persentase Bobot Tetas, Daya Tetas dan Mortalitas Embrio pada Itik Pengging
}

\author{
T. Suselowati, E. Kurnianto*, S. Kismiati \\ Program Studi Peternakan, Fakultas Peternakan dan Pertanian, Universitas Diponegoro, Semarang, Indonesia \\ 50275
}

Dikirim 20 Mei 2019; Diterima 23 Juli 2019

\begin{abstract}
ABSTRAK
Tujuan penelitian ini adalah mengevaluasi bobot telur, bobot tetas, persentase bobot tetas, daya tetas dan mortalitas embrio berdasarkan ukuran indeks bentuk dan surface area telur itik Pengging. Penelitian menggunakan 1112 butir telur itik Pengging yang berasal dari 78 ekor jantan dan 772 ekor betina itik Pengging (nisbah perkawinan jantan : betina $=1: 10$ ). Rancangan percobaan yang digunakan adalah Rancangan Acak Lengkap (RAL). Perlakuan terdiri dari 3 kategori indeks bentuk telur atau surface area dengan 7 periode penetasan sebagai ulangan. Indeks bentuk telur adalah lonjong $(68,78-78,93)$, normal $(78,94-86,45)$ dan bulat $(86,46-98,59)$ dan surface area adalah sempit $\left(66,94-74,58 \mathrm{~cm}^{2}\right)$, sedang $\left(74,59-84,85 \mathrm{~cm}^{2}\right)$ dan luas $\left(84,86-110,70 \mathrm{~cm}^{2}\right)$. Data yang diperoleh dianalisis menggunakan model klasifikasi satu arah dan regresi-korelasi antara indeks bentuk telur $(\mathrm{X})$ dan surface area telur $(\mathrm{Y})$. Hasil penelitian menunjukkan ada hubungan antara indeks bentuk telur dengan surface area telur, memiliki model persamaan regresi sederhana $\mathrm{Y}=121,59998-0,50643 \mathrm{X}, \mathrm{R}^{2}=0,1376$ dan berkorelasi negatif yaitu $-0,37097$, sedangkan hubungan indeks bentuk telur dengan bobot telur memiliki model persamaan regresi sederhana $\mathrm{Y}=77,42967-0,16281 \mathrm{X}, \mathrm{R}^{2}=0,0134$ dan nilai korelasinya $-0,11580$. Hasil analisis ragam menunjukkan bahwa bobot tetas, daya tetas dan mortalitas total dipengaruhi oleh indeks bentuk telur maupun surface area telur $(\mathrm{P}<0,05)$. Mortalitas hari ke 8-25 tidak dipengaruhi oleh indeks bentuk telur, namun dipengaruhi oleh surface area telur $(\mathrm{P}<0,05)$. Persentase bobot tetas, mortalitas hari ke 1-7 dan hari ke 26-28 tidak dipengaruhi oleh indeks bentuk telur maupun surface area telur. Kesimpulan penelitian ini adalah indeks bentuk telur lonjong serta surface area telur luas dipilih untuk mendapatkan bobot telur, bobot tetas, persentase bobot tetas dan daya tetas yang tinggi serta mortalitas embrio yang rendah pada itik Pengging.
\end{abstract}

Kata Kunci: Itik Pengging, Indeks bentuk, Surface area, Regresi, Korelasi, Produktivitas

\section{Relation of Egg Shape Index and Egg Surface Area to Egg Weight, Hatch Weight, Hatch Weight Percentage and Embryo Mortality in Pengging Ducks}

\begin{abstract}
The objectives of this research were to evaluate egg weight, hatch weight, hatch weight percentage, hatchability and embryo mortality based on the shape index and surface area of the Pengging duck eggs. The 1112 Pengging duck eggs from 78 males and 772 females (mating ratio male: female $=1: 10$ ) were used. The completely randomized design (CRD) was applied as experimental design. The treatment consisted of 3 categories of shape index or surface area with 7 replications of hatching period. The shape index was oval (68.78-78.93), normal (78.94-86.45) and round (86.46-98.59) and the surface area was narrow $\left(66.94-74.58 \mathrm{~cm}^{2}\right)$, moderate $\left(74.59-84.85 \mathrm{~cm}^{2}\right)$ and wide $\left(84.86-110.70 \mathrm{~cm}^{2}\right)$. The data obtained were analyzed using one-way classification model and regression-correlation between egg shape index $(X)$ and egg surface area $(Y)$. There was a relationship between the egg shape index with the egg surface area, which was the simple regression equation model of $Y=$ $121.59998-0.50643 X, R^{2}=0.1376$ and negatively correlated that was -0.37097 , while the relationship between the egg shape index and egg weight had a simple regression equation model $Y=77,442967-0,16281 X, R^{2}=0.0134$ and the correlation that was $-0,11580$. The results of analysis of the variance showed that hatch weight, hatchability and total mortality were affected by the egg shape index or egg surface area $(P<0.05)$. Weight loss and mortality of days $8-25$ were not affected by the egg shape index, but it was affected by the egg surface area $(P<0.05)$. The hatch weight percentage, mortality of days $1-7$ and days 26 28 were not affected by the egg shape index and egg surface area. In conclusion, the oval shape index and wide surface area could be used to obtain high of egg weight, hatch weight, hatch weight percentage and hatchability, and low embryo mortality in Pengging duck.
\end{abstract}

Keywords: Pengging duck, Shape index, Surface area, Regression, Correlation, Productivity

\section{PENDAHULUAN}

Jawa Tengah merupakan salah satu provinsi dengan penghasil telur itik yang banyak dengan tingkat keanekaragaman genetis tinggi. Statistik Peternakan Jawa Tengah (2014), mempublikasikan bahwa terjadi peningkatan produksi telur itik dari tahun 2011 hingga

*Penulis Korespondensi: Edy Kurnianto

Alamat: Fakultas Peternakan dan Pertanian, Universitas

Diponegoro, Kampus Tembalang, Semarang 50275

Email: kurniantoedy17@gmail.com
2013 sebesar 2.760 ton telur itik dengan ratio kenaikan $2,13 \%$. Jenis itik yang dikembangkan saat ini meliputi itik Pengging, itik Tegal dan itik Magelang (Wulandari et al., 2015). Itik Pengging merupakan plasma nutfah yang perlu dikembangbiakkan dan dilestarikan.

Itik Pengging berasal dari Kecamatan Banyudono, Kabupaten Boyolali, Jawa Tengah. Karakteristik itik Pengging memiliki badan yang bulat bila berdiri tegak menyerupai botol, warna kaki dan paruh hitam dan tipis, mata lebar, kepala kecil, leher agak panjang, masa produksi 9-11 bulan per tahun dan 
warna kerabang telur biru muda kehijauan (Wulandari et al., 2015). Menurut data Kementerian Pertanian tahun 2010, populasi itik Pengging tercatat 34.369 ekor. Keunggulan itik Pengging diantaranya memiliki produksi telur yang lebih banyak dibandingkan dengan itik yang lain, misalnya itik Magelang dan itik Tegal (Suprijatna et al., 2008). Itik ini merupakan jenis itik petelur unggul yang dapat menghasilkan produksi telur sebanyak 110 sampai 130 butir/tahun (Mulyono et al. 2017).

Sistem pemeliharaan masyarakat lokal yang belum layak dan masih bersifat tradisional (manajemen terkontrol belum diterapkan dalam pemeliharaan) menyebabkan produktivitas itik Pengging kurang maksimal. Optimalisasi sangat penting karena tidak hanya bertujuan melestarikan plasma nutfah Indonesia, khususnya Jawa Tengah, tetapi juga berfungsi untuk mendukung usaha ternak lokal serta dapat meningkatkan perekonomian masyarakat. Salah satu cara yang dapat dilakukan untuk optimalisasi adalah pemilihan karakter telur yang dilihat dari ukuran indeks bentuk telur dan surface area telur. Pengukuran indeks bentuk telur mengeskpresikan perbandingan dari lebar dan panjang telur, sedangkan surface area telur merupakan suatu teknik yang digunakan sebagai indikasi mengukur tingkat keluasan permukaan telur dan menjadi perhitungan geometri yang penting unuk industri peternakan, hal ini karena dapat digunakan untuk memprediksi bobot anak dan daya tetas (Zhou et al., 2008).

Kesuksesan dalam proses penetasan tergantung pada beberapa faktor diantaranya kualitas telur, bobot telur dan daya tetas (Widiyaningrum et al., 2016). Bobot telur dan daya tetas yang tinggi dapat diperoleh dari teknik saat menyeleksi telur tetas. Daya tetas yang tinggi dapat diperoleh jika tingkat mortalitas embrio rendah. Penelitian sebelumnya mengkaji mengenai kualitas daya tetas yang dipengaruhi oleh ukuran indeks bentuk telur. Bentuk telur dapat mempengaruhi daya tetas karena komposisi internal dalam telur (Kurnianto et al., 2010), dimana telur yang lonjong dan luas diduga memiliki komposisi internal telur yang lebih tinggi sehingga nantinya dapat berdampak pada bobot telur, bobot tetas dan mortalitas embrio. Bobot telur berkorelasi positif dengan bobot tetas (Mbajiorgu dan Ramaphala, 2014), sehingga bobot tetas yang tinggi diperoleh dari bobot telur yang tinggi.

Tujuan penelitian ini adalah untuk menganalisis hasil evaluasi bobot telur, bobot tetas, persentase bobot tetas, daya tetas dan mortalitas embrio berdasarkan ukuran indeks bentuk dan surface area telur itik Pengging. Tujuan lainnya yaitu melestarikan plasma nutfah di Jawa Tengah serta membantu dalam program seleksi bibit unggul.

\section{MATERI DAN METODE}

Penelitian ini dilaksanakan selama 3 bulan untuk pengambilan telur Itik Pengging sampai pengambilan data. Analisis data dilaksanakan di
Laboratorium Genetika, Pemuliaan dan Reproduksi, Fakultas Peternakan dan Pertanian, Universitas Diponegoro.

\section{Materi Penelitian}

Penelitian ini menggunakan 1112 butir telur itik Pengging yang berasal dari Balai Budidaya dan Pembibitan Ternak Terpadu (BBPTT) Taman Ternak Itik Banyubiru, Desa Ngrapah, Kecamatan Banyubiru, Kabupaten Semarang, Jawa Tengah dari 850 ekor itik Pengging umur $\pm 12-17$ bulan yang terdiri dari 772 ekor induk dan 78 ekor pejantan dengan umur yang sama (mating ratio jantan:betina adalah 1:10). Alat yang digunakan adalah egg tray, timbangan elektrik dengan ketelitian 0,01 g berkapasitas $500 \mathrm{~g}$, jangka sorong, mesin tetas (setter dan hatcher), candler, tempat pakan dan minum. Pakan yang diberikan mengandung kandungan EM 2836,74 Kkal/Kg dan PK $14,26 \%$ (Mustofa, 2018), jaring pembungkus telur untuk membedakan telur yang ditetaskan, dan desinfektan.

\section{Metode Penelitian}

Penelitian ini menggunakan rancangan percobaan Rancangan Acak Lengkap (RAL). Perlakuan terdiri dari 3 kategori indeks bentuk telur serta surface area telur dengan 7 periode penetasan sebagai ulangan. Pengkategorian dihitung dengan cara mencari nilai rata-rata dan simpangan baku, kemudian batas-batas kategori dihitung dengan menambah dan mengurangi nilai rata-rata dengan simpangan baku (Arikunto, 2013). Hasil dari pengkategorian secara keilmuan statistik tersebut diperoleh sebagai berikut indeks bentuk telur adalah lonjong $(68,78-78,93)$, normal $(78,94-86,45)$ dan bulat $(86,46-98,59)$, sedangkan surface area telur adalah sempit $(66,94-$ $\left.74,58 \mathrm{~cm}^{2}\right)$, sedang $\left(74,59-84,85 \mathrm{~cm}^{2}\right)$ dan luas $(84,86-$ $\left.110,70 \mathrm{~cm}^{2}\right)$.

Pengukuran panjang dan lebar telur menggunakan jangka sorong dan bobotnya dengan timbangan elektrik. Koleksi telur dilakukan selama 3 hari yang disebut dengan 1 periode koleksi. Telur dimasukkan dalam mesin setter pada hari ke 4 . Telur di teropong dengan lampu (candling) pada hari 7 dan hari 25 , telur dikeluarkan dari mesin setter, kemudian telur dibungkus dengan jaring pembungkus dan dimasukkan dalam mesin hatcher. Lama menetas sampai \pm 28 hari. Telur yang telah menetas menjadi day old duck (DOD) dan dikeluarkan dari mesin hatcher kemudian ditimbang dan dicatat kode DOD serta bobotnya. Perhitungan indeks bentuk telur (Panda, 1996), surface area telur (Rath et al., 2015), persentase bobot tetas (Shafey et al., 2014), mortalitas embrio (Alasahan dan Copur, 2016) dan daya tetas (Bobbo et al., 2013) dihitung dengan rumus :

$$
\begin{array}{ll}
\text { Indeks Bentuk Telur } & =\frac{\text { lebar telur }}{\text { panjang telur }} \times 100 \\
\text { Surface Area } & =4 \pi\left(\frac{1}{4(\text { panjang }+ \text { lebar })}\right)^{2}
\end{array}
$$


Persentase Bobot Tetas $=\frac{\text { bobot Day Old Duck (DOD) }}{\text { bobot telur }} \times 100 \%$

Mortalitas Embrio $=\frac{\text { jumlah embrio mati }}{\text { jumlah telur yang fertil }} \times 100 \%$

Daya Tetas $\quad=\frac{\text { jumlah Day Old Duck (DOD) }}{\text { jumlah telur yang fertil }} \times 100 \%$

\section{Analisis Data}

Data yang diperoleh dianalisis dengan General Linear Model (GLM) program Statistical Analysis System (SAS) University Edition. Model linier aditif untuk menganalisis data penelitian ini:

$$
\mathrm{Y}_{\mathrm{ij}}=\mu+\tau_{\mathrm{i}}+\varepsilon_{\mathrm{ij}}, \mathrm{i}=(1,2,3) \text { dan } \mathrm{j}=(1,2, \ldots \ldots, \mathrm{n})
$$

\section{Keterangan:}

Yij = Pengamatan parameter pada individu DOD ke-j dari kategori ke-i.

$\mu \quad=$ Nilai tengah.

$\tau_{\mathrm{i}} \quad=$ Pengaruh perbedaan kategori telur (indeks bentuk telur atau surface area telur)

$\varepsilon_{\mathrm{ij}} \quad=$ Pengaruh galat percobaan

Apabila parameter menunjukkan perbedaan yang nyata $(\mathrm{P}>0.05)$ maka dilanjutkan dengan uji Duncan's New Multiple Range Test (DMRT) menurut Shinjo (1990).

$$
\text { DMRT }=\text { qp }(\mathrm{i}, \mathrm{df}) \sqrt{(}(M S E 1 / H)
$$

Keterangan :

DMRT = Duncan's Multiple Range Test

Qp (r, df) = Peluang P, perlakuan ke-I dan nilai dari derajat bebas (df) dari tabel Duncan

$\mathrm{MS}_{\mathrm{E}} \quad=$ Rata-rata jumlah kuadrat dari ANOVA

$\bar{H} \quad$ = Rata-rata harmonik

Hubungan antara indeks bentuk telur dan surface area telur serta hubungan indeks bentuk telur dengan bobot telur dihitung nilai regresi dan korelasinya. Persamaan regresi indeks bentuk telur $(\mathrm{X})$ terhadap surface area telur (Y), dan indeks bentuk telur (X) terhadap bobot telur (Y) dianalisis menurut Sembiring (1995):

$$
\mathrm{Y}=\alpha+\beta \mathrm{X}+\varepsilon
$$

Keterangan :

$$
\begin{array}{ll}
\alpha, \beta & =\text { Koefisien garis regresi } \\
\mathrm{Y} & =\text { Variabel terikat (surface area telur atau } \\
& \text { bobot telur) } \\
\mathrm{X} & =\text { Variabel bebas (indeks bentuk telur) } \\
\varepsilon & =\text { Galat }
\end{array}
$$

Uji korelasi digunakan untuk mengukur nilai keeratan hubungan antar variabel (Nugroho, 2005). Uji korelasi yang digunakan dalam penelitian ini adalah korelasi Pearson karena variabel yang diteliti bersifat data interval.

\section{HASIL DAN PEMBAHASAN}

\section{Hubungan Indeks Bentuk Telur dengan Surface Area Telur}

Hasil analisis regresi antara indeks bentuk telur dan surface area telur pada itik Pengging menunjukkan model persamaan regresinya adalah linear. Persamaan regresinya yaitu $\mathrm{Y}=121,59998-0,50643 \mathrm{X} \mathrm{R}^{2}=$ 0,1376. Nilai $\mathrm{R}^{2}$ yang mendekati angka nol, menunjukkan nilai keeratan antara variabel $\mathrm{X}$ (indeks bentuk telur) dan Y (surface area telur) bersifat lemah. Koefisien determinasi 0,1376 berarti bahwa variabel $\mathrm{X}$ mempengaruhi secara langsung variabel $\mathrm{Y}$ sebesar $13,76 \%$ sedangkan sisanya yaitu $86,24 \%$ dipengaruhi oleh faktor lain. Indeks bentuk telur dan surface area, sama-sama diperoleh dari perhitungan lebar dan panjang telur (Rath et al., 2015; Bobbo et al., 2013), sehingga keduanya memiliki hubungan keeratan yang saling mempengaruhi satu sama lainnya.

Indeks bentuk telur dengan surface area telur memiliki korelasi negatif sebesar $-0,37097$. Korelasi dengan hasil negatif mempunyai arti semakin besar nilai yang ditunjukkan variabel $\mathrm{X}$ akan semakin kecil nilai variabel $\mathrm{Y}$ dan sebaliknya (Kurniawan dan Yuniarto, 2016), sedangkan dilihat dari besaran nilai korelasi masuk dalam kategori rendah. Menurut Wibisono (2003), koefisien korelasi diatas 0,2 sampai 0,4 menunjukkan korelasi yang rendah. Faktor lain seperti cekaman panas, tidak mempengaruhi secara signifikan terhadap panjang dan lebar telur (Setiawati et al., 2016), sehingga aman dalam penentuan indeks bentuk dan surface area telur sebelum dilakukan penetasan.

\section{Bobot Telur}

Indeks bentuk telur, surface area telur dan bobot telur terjadi secara bersamaan, sehingga hubungan antara bobot telur dengan indeks bentuk dan surface area bukan causative, tetapi korelasi. Persamaan regresinya adalah $\mathrm{Y}=77,42967-0,16281 \mathrm{X} \mathrm{R}^{2}=$ 0,0134 dengan nilai koefisien determinasinya $1,34 \%$. Hal ini menunjukkan bahwa sama halnya dengan hubungan indeks bentuk telur dan surface area yang nilai koefisien determinasinya rendah, mendekati angka nol.

Hasil analisis sebelumnya menunjukkan terdapat korelasi yang bersifat negatif antara indeks bentuk telur dengan surface area telur, hal ini sama dengan hasil korelasi antara indeks bentuk telur dengan bobot telur yang bernilai negatif $-0,11580$, sehingga faktor yang mempengaruhi tampilan produksi indeks bentuk telur dengan bobot telur memiliki sifat yang sama yaitu berbanding terbalik, semakin besar nilai indeks bentuk telur maka bobot telurnya semakin rendah, namun dapat dilihat nilai korelasi terbilang rendah, menurut Wibisono (2003), koefisien korelasi kurang dari 0,2 korelasi dapat diabaikan. Faktor yang mempengaruhi besar kecilnya bobot telur yaitu komposisi perbandingan internal telur yaitu kuning dan putih telur yang lebih besar. Menurut Purwati et al. 
(2015) bahwa bobot telur dipengaruhi besar kecilnya ukuran kuning telur. Bobot kuning telur dipengaruhi oleh perkembangan ovarium, bobot badan induk, umur dewasa kelamin (Tugiyanti dan Iriyanti, 2012).

\section{Bobot Tetas}

Indeks bentuk telur menunjukkan hasil yang berbeda nyata $(\mathrm{P}<0,05)$ terhadap bobot tetas itik Pengging, namun telur normal dan bulat tidak berbeda nyata. Telur yang paling tinggi bobot tetasnya yaitu telur dengan kategori indeks bentuk lonjong, dibandingkan telur dengan indeks bentuk normal dan bulat (Tabel 1). Bobot tetas memiliki hubungan yang erat dengan bobot telur (Mbajiorgu dan Ramaphala, 2014), semakin besar nilai bobot telur akan menentukan besarnya bobot tetas. Bobot tetas memiliki korelasi positif dengan bobot telur (Hasan, 2005), sehingga semakin besar bobot telur maka semakin besar pula bobot tetasnya.

Surface area telur juga mempengaruhi besarnya bobot tetas $(\mathrm{P}<0,05)$, bobot tetas tertinggi terdapat pada telur dengan dengan surface area luas, dibandingkan surface area sedang dan sempit (Tabel 2). Bobot tetas yang besar dihasilkan oleh surface area yang luas dan nilai indeks bentuk telur yang lonjong karena karena ukuran diameter telur yang besar. Rata-rata bobot tetas itik Pengging yaitu 38,86 g, dibandingkan dengan ratarata bobot tetas itik Magelang masih dalam kategori sama. Menurut Menteri Pertanian (2013), bobot tetas day old duck (DOD) itik Magelang sebesar 35-45 g/ekor. Bobot telur menjadi salah satu pertimbangan yang sangat penting dalam proses seleksi telur tetas, hal ini supaya diperoleh bobot tetas yang baik. Selain bentuk telur, syarat telur tetas yang baik meliputi ketebalan kerabang dan kebersihan cangkang (Asmarawati et al., 2013).

\section{Persentase Bobot Tetas}

Indeks bentuk telur maupun surface area telur menunjukkan hasil yang berbeda tidak nyata $(\mathrm{P}>0,05)$ terhadap persentase bobot tetas. Nilai persentase bobot tetas dilihat dari semua kategori telur berdasarkan indeks bentuk telur dan surface area telur (Tabel 1) (Tabel 2), masih dibawah standar yang baik. Menurut Sudaryani dan Santoso (1994), bobot tetas yang normal memiliki persentase sebesar $70 \%$ dari bobot telur, apabila besar bobot tetas kurang dari hasil perhitungan tersebut maka proses penetasan dikatakan belum baik. Faktor yang mempengaruhi besar kecilnya nilai persentase bobot tetas yaitu besarnya bobot day old duck (DOD) dan bobot telur saat masuk mesin tetas, sesuai dengan rumus perhitungan persentase bobot tetas, dimana pembagian antara bobot DOD dengan bobot telur dan dikali 100\% (Shafey et al., 2014)

\section{Daya tetas}

Indeks bentuk telur antara kategori lonjong dan bulat menunjukan hasil yang berbeda nyata $(\mathrm{P}<0,05)$ terhadap daya tetas (Tabel 1). Menurut Sa'diah et al. (2015) bahwa teknis pada waktu memilih telur tetas atau seleksi telur tetas (bentuk telur, bobot telur, keadaan kerabang, warna kerabang dan lama penyimpanan) dan teknis operasional dari petugas yang menjalankan mesin tetas (temperatur,

Tabel 1. Penampilan produksi Itik Pengging pada berbagai perbedaan indeks bentuk telur

\begin{tabular}{|c|c|c|c|}
\hline \multirow{2}{*}{ Parameter yang diamati } & \multicolumn{3}{|c|}{ Indeks Bentuk Telur } \\
\hline & Lonjong & Normal & Bulat \\
\hline Bobot tetas $(\mathrm{g})$ & $41,34 \pm 5,35^{\mathrm{a}}$ & $38,63 \pm 5,15^{\mathrm{b}}$ & $38,90 \pm 4,99^{b}$ \\
\hline Persentase bobot tetas (\%) & $51,57 \pm 3,75^{\mathrm{ns}}$ & $50,84 \pm 3,48^{\mathrm{ns}}$ & $51,15 \pm 3,85^{\mathrm{ns}}$ \\
\hline Daya tetas $(\%)$ & $41,70 \pm 11,25^{\mathrm{a}}$ & $38,21 \pm 2,96^{\mathrm{ab}}$ & $28,03 \pm 13,91^{b}$ \\
\hline Mortalitas hari 1-7 (\%) & $23,37 \pm 18,14^{\mathrm{ns}}$ & $24,17 \pm 5,35^{\mathrm{ns}}$ & $27,31 \pm 13,24^{\mathrm{ns}}$ \\
\hline Mortalitas hari 8-25 (\%) & $21,05 \pm 11,12^{\mathrm{ns}}$ & $25,90 \pm 6,18^{\mathrm{ns}}$ & $26,55 \pm 8,29^{\mathrm{ns}}$ \\
\hline Mortalitas hari 26-28 (\%) & $22,90 \pm 15,34^{\mathrm{ns}}$ & $28,85 \pm 10,03^{\mathrm{ns}}$ & $30,87 \pm 15,04^{\mathrm{ns}}$ \\
\hline Mortalitas Total (\%) & $48,30 \pm 11,25^{\mathrm{b}}$ & $51,79 \pm 2,96^{\mathrm{ab}}$ & $61,97 \pm 13,91^{\mathrm{a}}$ \\
\hline
\end{tabular}

$\overline{\mathrm{a}, \mathrm{b}}$ superskrip yang berbeda pada baris yang sama menunjukkan perbedaan yang nyata $(\mathrm{P}<0,05)$, ns (non significan) $=$ berbeda tidak nyata $(\mathrm{P}>0,05)$.

Tabel 2. Penampilan produksi Itik Pengging pada berbagai perbedaan surface area telur

\begin{tabular}{|c|c|c|c|}
\hline \multirow[t]{2}{*}{ Parameter yang diamati } & \multicolumn{3}{|c|}{ Surface Area Telur } \\
\hline & Sempit & Sedang & Luas \\
\hline Bobot tetas $(\mathrm{g})$ & $34,32 \pm 4,60^{\mathrm{c}}$ & $38,37 \pm 4,36^{\mathrm{b}}$ & $44,00 \pm 4,63^{\mathrm{a}}$ \\
\hline Persentase bobot tetas (\%) & $50,67 \pm 3,91^{\mathrm{ns}}$ & $50,96 \pm 3,61^{\mathrm{ns}}$ & $51,20 \pm 3,16^{\mathrm{ns}}$ \\
\hline Daya tetas $(\%)$ & $29,51 \pm 15,32^{\mathrm{b}}$ & $36,75 \pm 3,50^{\mathrm{ab}}$ & $44,82 \pm 7,20^{\mathrm{a}}$ \\
\hline Mortalitas hari 1-7 (\%) & $18,79 \pm 11,55^{\mathrm{ns}}$ & $26,05 \pm 6,88^{\mathrm{ns}}$ & $19,99 \pm 6,88^{\mathrm{ns}}$ \\
\hline Mortalitas hari 8-25 (\%) & $32,88 \pm 11,52^{\mathrm{a}}$ & $25,78 \pm 5,10^{\mathrm{ab}}$ & $20,06 \pm 11,57^{b}$ \\
\hline Mortalitas hari 26-28 (\%) & $30,44 \pm 9,08^{\mathrm{ns}}$ & $28,58 \pm 11,10^{\mathrm{ns}}$ & $28,13 \pm 13,52^{\mathrm{ns}}$ \\
\hline Mortalitas Total (\%) & $59,33 \pm 15,32^{\mathrm{a}}$ & $53,25 \pm 3,50^{\mathrm{ab}}$ & $45,77 \pm 8,23^{\mathrm{b}}$ \\
\hline
\end{tabular}

$\overline{\mathrm{a}, \mathrm{b}, \mathrm{c}}$ superskrip yang berbeda pada baris yang sama menunjukkan perbedaan yang nyata $(\mathrm{P}<0,05)$, ns (non significan) $=$ berbeda tidak nyata $(\mathrm{P}>0,05)$. 
kelembapan, sirkulasi udara dan pemutaran telur) serta faktor yang terletak pada induk yang digunakan sebagai bibit dapat mempengaruhi besar kecilnya persentase daya tetas. Bentuk telur itik Pengging yang lonjong memiliki daya tetas yang tinggi karena telur Pengging relatif lebih kecil ukurannya dibandingkan itik lainnya, seperti Itik Magelang, sehingga kategori lonjong pada itik Pengging tidak sama dengan ukuran indeks bentuk telur lonjong pada telur Itik Magelang. Ukuran indeks bentuk telur yang baik untuk ditetaskan adalah berkisar 71-79 (Okatama et al., 2018), sehingga sesuai pada kategori lonjong pada telur itik Pengging yang berkisar 68,78-78,93.

Surface area telur antara kategori sempit dan luas menunjukan hasil yang berbeda nyata $(\mathrm{P}<0,05)$ terhadap persentase daya tetas (Tabel 2). Telur kategori surface area luas memiliki persentase daya tetas paling tinggi. Ukuran indeks bentuk telur dengan surface area telur, sesuai dengan pembahasan sebelumnya memiliki korelasi negatif, artinya semakin kecil angka indeks bentuk telur maka surface area nya semakin luas, sehingga daya tetas telur yang baik diperoleh dari telur kategori indeks lonjong dengan kategori surface area nya yaitu luas. Telur yang memiliki luas permukaan luas dapat menyebabkan proses penyerapan panas juga besar sehingga penguapan melalui pori-pori pada kerabang telur semakin banyak. Menurut Widyantara et al. (2017) bahwa pori-pori kerabang berfungsi untuk pertukaran gas dari dalam dan luar kerabang telur. Kerabang telur pada bagian tumpul memiliki jumlah pori-pori per satuan luas lebih banyak dibandingkan dengan pori-pori bagian yang lain (Kurtini et al., 2011).

\section{Mortalitas Embrio}

Indeks bentuk telur menunjukkan hasil yang tidak berbeda nyata terhadap mortalitas embrio hari ke 1-7, 8-25 dan 26-28, sedangkan mortalitas total menunjukkan hasil yang berbeda nyata $(\mathrm{P}<0,05)$ antara kategori lonjong dan bulat (Tabel 1). Perhitungan persentase mortalitas embrio dimulai telur masuk setter sampai masuk ke hatcher (hari ke 1-28). Telur yang paling tinggi mortalitasnya adalah kategori indeks bentuk telur bulat, dibandingkan telur dengan bentuk normal dan lonjong. Semakin tinggi nilai indeks bentuk telur cenderung menghasilkan mortalitas yang semakin tinggi. Kematian embrio selama proses pengeraman di setter dan penetasan di hatcer dapat terjadi karena pengaruh nutrisi yang terkandung dalam telur dan posisi embrio yang tidak menguntungkan. Menurut North (1978), saat pengeraman berlangsung posisi kuning telur dapat naik dan menempel pada bagian luar selaput putih telur. Kematian embrio paling rentan terjadi pada empat hari pertama dan tiga hari terakhir. Persentase mortalitas tertinggi terjadi pada awal dan akhir inkubasi pada saat penetasan (Tona et al., 2001).

Surface area telur menunjukkan hasil yang tidak berbeda nyata terhadap mortalitas hari ke 1-7 dan hari ke 26-28, sedangkan mortalitas embrio hari ke 8-25 dan mortalitas total menunjukkan hasil yang berbeda nyata $(\mathrm{P}<0.05)$ antara kategori sempit dan luas (Tabel 2).
Nilai mortalitas tertinggi terdapat pada telur kategori sempit, dibandingkan telur sedang dan luas. Semakin rendah nilai surface area telur menghasilkan mortalitas yang semakin tinggi, karena telur yang memiliki surface area sempit memiliki kemampuan dalam menahan bakteri masuk melalui cangkang relatif rendah disebabkan bentuk telur cenderung bulat serta kemampuan chalazae yang kurang baik. Jenis bakteri salmonella dapat dengan mudah menembus cangkang dan mengganggu proses perkembangan embrio (Berrang et al., 1999) sehingga dapat mengakibatkan embrio tidak dapat bertahan sampai berhasil menjadi DOD. Penelitian Willems et al. (2014) menyebutkan Chalazae, dapat menahan kuning telur berada dalam posisi tengah menjauh dari kerabang telur, membentuk penjagaan bagi bakteri yang mungkin menembus kerabang telur.

Nutrisi yang terkandung dalam telur juga mempengaruhi perkembangan embrio sampai telur menetas, hal ini karena nutrisi sangat dibutuhkan untuk mencukupi kebutuhan embrio. Bobot telur yang tinggi memiliki kandungan jumlah kuning telur dan putih telur tinggi (Romanoff dan Romanoff, 1975), hal ini menjadikan bobot tetas cenderung tinggi karena ketersediaan nutrisi untuk perkembangan embrio semakin banyak, sehingga mortalitas embrio semakin rendah. Komponen internal telur terdapat albumen yang turut melindungi embrio dari mikroba patogen dan menyediakan pasokan nutrisi (Yuan et al., 2013).

\section{KESIMPULAN}

Terdapat korelasi negatif antara indeks bentuk telur dengan surface area telur. Indeks bentuk telur yang lonjong dan surface area telur luas dapat dipilih untuk mendapatkan bobot telur, bobot tetas dan persentase bobot tetas yang tinggi serta mortalitas embrio yang rendah pada itik Pengging.

\section{UCAPAN TERIMA KASIH}

Penelitian ini didukung pendanaannya dari Universitas Diponegoro melalui "Hibah Penelitian Undip” No. 5871/UN7.4.3/PP/2017.

\section{DAFTAR PUSTAKA}

Angkow, M. E., J.R. Leke, E. Pudjihastuti dan L. Tangkau. 2017. Kualitas internal telur ayam MB 402 yang diberi ransum mengandung minyak limbah ikan Cakalang (Katsuwonus pelanis L). Jurnal Zootek 37(2): 232-241.

Alasahan, S. and A. G. Copur. 2016. Hatching characteristics and growth performance of eggs with different egg shapes. Brazilian Journal Poultry Science 18(1): 1-8.

Arikunto, S. 2013. Prosedur Penelitian: Suatu Pendekatan Praktik. PT. Rineka Cipta. Jakarta.

Asmarawati, A., Kustono, D. T. Widayati, S. Bintara dan Ismaya. 2013. Pengaruh dosis sperma yang 
diencerkan dengan $\mathrm{NaCl}$ fisiologis terhadap fertilitas telur pada inseminasi buatan ayam kampung. Buletin Peternakan 37(1) :1-5.

Berrang, M. E., J. F. Frank., R. J. Buhr., J. S. Bailey and N. A. Cox. 1999. Eggshell membrane structure and penetration by Salmonella typhimurium. Journal of Food Protection 62: 73-76.

Bobbo, A.G., M.S. Yahaya and S.S. Baba. 2013. Comparative assessment of fertility and harchability traits of three phenotype of local chicken in Adamawa State. IOSR Journal Agriculture Veterinary Science 4(2): 22-28.

Dinas Peternakan Propinsi Jawa Tengah. 2014. Buku Statistik Peternakan Tahun 2014. Dinas Peternakan dan Kesehatan Hewan Provinsi JawaTengah. Ungaran.

Gerber, N. 2006. Factors affecting egg quality in commercial laying hen: a review. Auckland (NZ): Poultry Industri Association of New Zealand.

Harmayanda, P. O. A., D. Rosyidi dan O. Sjofjan. 2016. Evaluasi kualitas telur dari hasil pemberian beberapa jenis pakan komersial ayam petelur. Jurnal Pembangunan dan Alam Lestari 7(1): 2532.

Hasan, S. M. 2005. Physiology, endocrinology, and reproduction: egg storage period and weight effect on hatchability. Poultry Science 84: 19081912.

Kurnianto, E., S. Johari dan Y. Fadliyah. 2010. Penampilan dan nilai heritabilitas beberapa sifat kuantitatif pada ayam Kedu. Jurnal Agromedia 58(1): 54-59.

Kurniawan, R. dan B. Yuniarto. 2016. Analisis Regresi: Dasar dan Penerapannya dengan R Edisi Pertama. PT. Kharisma Putra Utama Kencana. Jakarta.

Kurtini, T., K. Nova. dan D. Septinova. 2011. Produksi Ternak Unggas. Universitas Lampung. Bandar Lampung.

Mbajiorgu, C. A. and N. O. Ramaphala. 2014. Insight into egg weight and its impact on chick hatchweight, hatchability and subsequent growth indices in chickens-A review. Indian Journal of Animal Research 48(3): 209-213.

Menteri Pertanian. 2013. Keputusan Menteri Pertanian Nomor 701/Kpts/PD.410/2/2013 Tentang Penetapan Rumpun Itik Magelang. Menteri Pertanian.

Mulyono, A. D., W. Sumekar dan D. Sunarti. 2017. Analisis profitabilitas pengembangan usaha ternak itik Petelur di Kecamatan Banyubiru Kabupaten Semarang Jawa Tengah. Jurnal Ilmu Peternakan Terapan 1(1): 8-16.

Mustofa, F. 2018. Pengaruh Lebar antar Pubis Induk Itik Magelang terhadap Produksi Telur, Bobot Telur, Daya Tetas dan Bobot Tetas Day Old Duck. Skripsi. Fakultas Peternakan dan Pertanian. Universitas Diponegoro. Semarang.
North, N. O. 1978. Commercial Chicken Production Manual. $2^{\text {nd }}$ Edition. Avi Publishing Co.Inc. Connecticut.

Nugroho, B. 2005. Memilih Metode Statistik Penelitian dengan SPSS. Andi Offset. Yogyakarta.

Okatama, M. S., S. Maylinda dan V. M. A. Nurgiartiningsih. 2018. Hubungan bobot telur dan indeks telur dengan bobot tetas itik Dabung di Kabupaten Bangkalan. Jurnal Ternak Tropika 19(1): 1-8.

Panda, P. C. 1996. Shape and Texture. In textbook on egg and poultry technology. $3^{\text {rd }}$ ed. New Delhi.

Purwati, D., M. A. Djaelani dan E. Y. W. Yuniwarti. 2015. Indeks kuning telur (IKT), haugh unit (HU) dan bobot telur pada berbagai itik lokal di Jawa Tengah. Jurnal Biologi 4(2): 1-9.

Rasyaf, M. 1991. Pengelolaan Produksi Telur. Kanisius. Yogyakarta.

Rath, P. K., P. K. Mishra, B. K. Mallick and N. C. Behura. 2015. Evaluation of different egg quality traits and interpretation of their mode of inheritance in White Leghorns. Veterinary World 8(3): 449-452.

Romanoff, A. L. and A. J. Romanoff. 1975. The Avian Egg. $2^{\text {nd }}$ Ed. John Wiley and Sons, Inc. New York.

Sa'diah, I. N., D. Garnida dan A. Mushawwir. 2015. Mortalitas embrio dan daya tetas Itik Lokal (Anas sp.) berdasarkan pola pengaturan temperatur mesin tetas. Journal of Poultry Science 4(3): 1-12.

Sembiring, R. K. 1995. Analisis Regresi Edisi 2. Penerbit ITB. Bandung.

Setiawati, T., R. Afnan dan N. Ulupi. 2016. Performa produksi dan kualitas telur ayam petelur pada sistem litter dan cage dengan suhu kandang berbeda. Jurnal Ilmu Produksi dan Teknologi Hasil Peternakan 4(1): 197-203.

Shafey, T. M., A. H. Mahmoud, A. A. Alsobayel and M. A. Abouheif. 2014. Effects of in ovo administration of amino acids on hatchability and performance of meat chickens. South African Journal of Animal Science 44(2): 123130.

Shinjo, A. 1990. First Course in Statistics.1St Ed., University of Ryukyus. Nishihara-cho, Okinawa. Japan.

Sudaryani dan Santoso. 1994. Pembibitan Ayam Buras. Penebar Swadaya. Jakarta.

Suprijatna, E., U. Atmomarsono dan R. Kartasujana. 2008. Ilmu Dasar Ternak Unggas. Cetakan ke2. Penebar Swadaya. Jakarta.

Tona, K. F. Bamelis., W. Coucke., V. Bruggeman and E. Decuypere. 2001. Relationship between broiler breeder's age and egg weight loss and embryonic mortality during incubation in largescale conditions. Journal of Applied Poultry Research 10(3): 221-227.

Tugiyanti, E. dan N. Iriyanti. 2012. Kualitas eksternal telur ayam petelur yang mendapat ransum 
dengan penambahan tepung ikan fermentasi menggunakan isolat prosedur antihistamin. Jurnal Aplikasi Teknologi Pangan 1(2): 44-47.

Tullet, S. G. 1990. Science and the art of incubation. Poultry Science 69: 1-15.

Van der Pol, C. W., I. A. M. van Roovert-Reijrink, C. M. Maatjens, $H$. van den Brand and $R$. Molenaar. 2013. Effect of relative humadity during incubation at a set eggshell temperature and brooding temperature posthatch on embryonic mortality and chick quality. Poultry Science 92(8): 2145-2155.

Wibisono, D. 2003. Riset Bisnis: Panduan bagi Praktisi dan Akademisi. PT. Gramedia Pustaka Utama. Jakarta.

Widiyaningrum, P., Lisdiana and N. R. Utami. 2016. Egg Production and hatchability of local ducks under semi intensive vs extensive managements. Journal of the Indonesian Tropical Animal Agriculture 41(2): 77-82.

Widyantara, P. R. A., G. A. M. K. Dewi dan I. N. T. Ariana. 2017. Pengaruh lama penyimpanan terhadap kualitas telur konsumsi ayam Kampung dan ayam Lohman Brown. Majalah Ilmiah Peternakan 20(1): 5-11.

Willems, E., E. Decuypere, J. Buyse and N. Everaert. 2014. Importance of albumen during embryonic development in avian species, with emphasis on domestic chicken. World's Poultry Science Journal 70(3): 503-517.

Wulandari, D., Sunarno dan T. R. Saraswati. 2015. Perbedaan Somatometri Itik Tegal, Itik Magelang dan Itik Pengging. Jurnal Akademika Biologi 4(3): 16-22.

Yuan, J. B. Wang, Z. Huang, Y. Fan, C. Huang and Z. Hou. 2013. Comparisons of egg quality traits, egg weigh loss and hatchability between striped and normal duck eggs. British Poultry Science 54(2): 265-269.

Zhou, P., W. Zheng, C. Zhao, C. Shen and G. Sun. 2008. Egg volume and surface area calculations based on machine vision. Proceeding of the Second IFIP International Conference on Computer and Computing Technologies in Agriculture (CCTA2008). Beijing, China. pp. 1647-1653. 